\title{
Erratum to: Familial chromosomal translocation X; 22 associated with infertility and recurrent $X$ mosaicism
}

Juliana Dourado Grzesiuk ${ }^{1 *}$, Ciro Silveira Pereira², Carlos Henrique Paiva Grangeiro',

Clarissa Gondim Picanço-Albuquerque ${ }^{1}$, Flávia Gaona Oliveira-Gennaro ${ }^{1}$, Filipe Brum Machado³,

Enrique Medina-Acosta ${ }^{3}$, Ester Silveira Ramos ${ }^{1}$, Maisa Yoshimoto ${ }^{4}$ and Lucia Martelli ${ }^{1}$

\section{Erratum}

Unfortunately, the original version of this article [1] contained an error. Figure 2a was missing.

The correct version of Fig. 2a,b can be found below. Figure 2 has been corrected in the original article [1] and is also included correctly below.

\section{Author details \\ ${ }_{1}^{1}$ Genetics Department, Ribeirão Preto Medical School, University of Sao Paulo, Ribeirao Preto 14049-900, Brazil. ${ }^{2}$ Center of Biotecnology and Cellular Therapy, San Raphael Hospital, Salvador 41253-190, Brazil. ${ }^{3}$ Center of Biosciences and Biotechnology, Darcy Ribeiro State University of Northern of Rio de Janeiro, Campos dos Goytacazes 28013-600, Brazil. ${ }^{2}$ Department of Medical Genetics, Faculty of Medical and Dentistry, University of Alberta, Edmonton, Canada.}

Published online: 05 July 2016

\section{Reference}

1. Grzesiuk JD, Pereira CS, Grangeiro CHP, Picanço-Albuquerque CG, Oliveira-Gennaro FG, Machado FB, Medina-Acosta E, Ramos ES, Yoshimoto M and Martelli L. Familial chromosomal translocation X; 22 associated with infertility and recurrent $X$ mosaicism. Mol Cytogenet. 2016;9:45. doi:10.1186/s13039-016-0249-5.

\footnotetext{
*Correspondence: juli_dourado@hotmail.com

${ }^{1}$ Genetics Department, Ribeirão Preto Medical School, University of Sao Paulo, Ribeirao Preto 14049-900, Brazil

Full list of author information is available at the end of the article

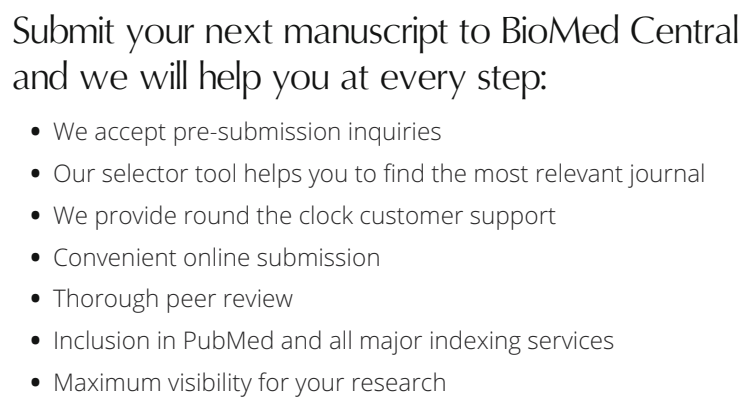
and we will help you at every step:

- We accept pre-submission inquiries

- Our selector tool helps you to find the most relevant journal

- We provide round the clock customer support

- Convenient online submission

- Thorough peer review

- Inclusion in PubMed and all major indexing services

- Maximum visibility for your research

Submit your manuscript at www.biomedcentral.com/submit 


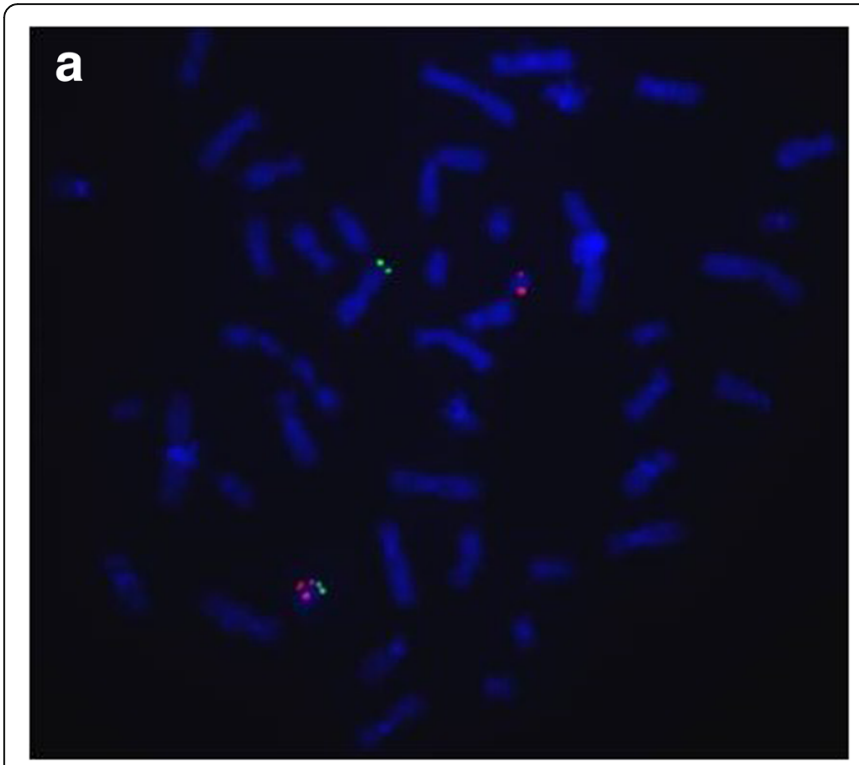

b

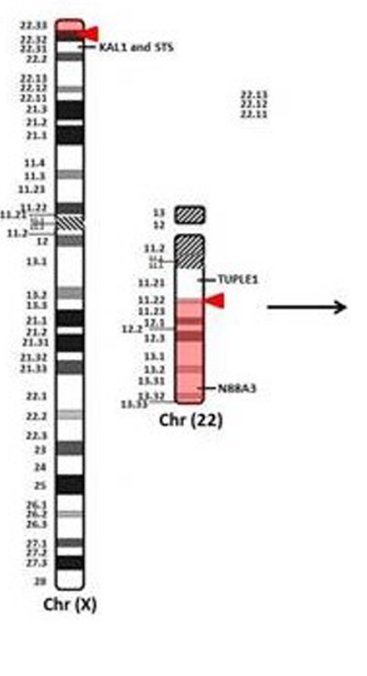

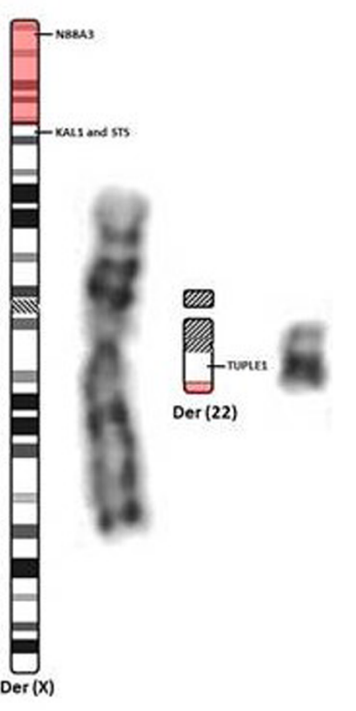

Fig. 2 FISH and Cytogenetic analyses of the translocation cariers. a FISH technique from patient A2 showing the subtelomeric probe of chromosome 22 (in green) in the distal portion of the short arm of the translocated X chromosome, while probe for TUPLE1 gene is located at band q11.21 (in red), remaining on the der(22). $\mathbf{b}$ On the left side the ideograms from normal chromosomes $X$ and 22 show the breakpoints (red arrow) and the translocated segments (shaded in red). On the right side are the schematic ideograms and the GTG banding pattern of the derivative chromosomes 